\title{
Multifactorial parametric model for assessing and making organizational decisions to ensure the quality of construction
}

\author{
Pavel Zhuravlev, Evgeniy Bachus and Irina Markova* \\ Moscow State university of civil engineering, Yaroslavskoye Shosse, 26, Moscow, 129337, Russia
}

\begin{abstract}
As noted by a number of experts in the field of the quality of construction of capital construction objects, at present there are no industry-specific methods for assessing the quality of construction and installation works in construction. The quality assessment and acceptance of capital construction objects is carried out according to the criterion of compliance with the requirements established in the project documentation, the working documentation prepared on its basis and the requirements established in the regulatory documents. It should be noted that the more complex the object, the larger the construction volume, the longer the construction period of the object and the harder it is to achieve full compliance of the object with the established requirements due to the lack of a methodology for choosing organizational decisions, as well as changing regulatory requirements, technological variability, errors.The current situation necessitated the development of an assessment model and the adoption of organizational decisions to ensure the quality of construction. This article highlights and discusses the main factors affecting the quality of organizational decisions. A system for assessing the level of quality assurance of construction is proposed, taking into account the quality of organizational decisions and the main factors cited.
\end{abstract}

\section{Introduction}

Quality assurance in the implementation of investment and construction activities in the field of atomic energy use, being a priority area of activity not only for the developer, but also for other participants in the investment process, requires the formation and implementation of new organizational forms and schemes for the implementation of such activities that do not contradict the current legislation in the field of urban planning and use of atomic energy with unconditional priority of nuclear and radiation safety. The emergence of new organizational forms and schemes for the implementation of investment and construction activities will not only cause a change in the distribution of functions, rights, duties, responsibilities, but also transform their very saturation and target orientation. A promising direction in the field of construction is the use of engineering management schemes at the corporate level of construction.

This scheme is based on the separation of functions related to the direct organization of construction such as: preparation, planning, construction management, its material and

\footnotetext{
*Corresponding author: markova@mgsu.ru
} 
technical support. Within the framework of such a scheme, the powers are radically redistributed, an emphasis is placed on the functioning of a new entity of investment and construction activity - the organizer of construction.

In this regard, quality control as an element of the general system of construction organization will require adjustments in order to ensure the solution of the main tasks in the field of construction production - reducing the cost and construction time.

\section{Methods}

It seems appropriate to conduct an assessment using methods that increase the validity of organizational decisions to ensure the quality of the construction of nuclear power facilities:

- prognostic analysis (involves the establishment of stable trends of change at the levels of the hierarchy);

- $\quad$ comparative analysis (correlates the forms and methods of organization);

- diagnostic analysis (establishes a causal relationship forms and methods of management);

- detailed analysis (identifies the reasons for the transformation of the elements and characteristics of the organization and forms of exposure).

One of the main criteria for the quality of a capital construction project is its reliability, in the context of the organizational and technological component [1,2] which should be understood as the ability of organizational, technological and economic decisions to maintain the projected quality characteristics within specified limits. In the appendix of the topic of this article and the research conducted by the authors [3-6], as well as related scientific research [7-10], it can be argued that the quality of organizational decisions depends on a number of factors.

Factor 1. The quality laid down when choosing a scheme and method of construction of the object, the distribution of functionality between the main participants of construction, the creation of a system of relations between the participants of construction [11-16]:

1.1 the choice of the organizational structure of the facility.

The basis of the organizational structure of the facility is the distribution of functions between the construction participants. The main options for the distribution of functions may be as follows:

- the property developer independently performs engineering surveys, design, carries out construction;

- $\quad$ the property developer independently performs engineering surveys, design and engages the construction organization in construction (it is possible to transfer part of the functions of the property developer to the technical customer);

- the property developer independently performs engineering surveys, and involves various organizations involved in the preparation of project documentation and construction respectively in design and construction works (with the possibility of transferring part of the property developer's functions to a technical customer);

- the property developer engages various organizations involved in engineering surveys, design and construction, carrying out engineering surveys, preparation of project documentation and construction, respectively (it is possible to transfer part of the functions of the builder to a technical customer);

- the property developer engages in engineering surveys, design and construction one organization performing engineering surveys, preparation of project documentation and construction (the property developer's functions are performed independently) — an engineering construction scheme;

- the property developer engages in an engineering survey, design and 
construction one organization that carries out engineering surveys, the preparation of project documentation and construction (with some functions of the builder being performed with the involvement of a technical customer) - an engineering construction scheme with the participation of a technical customer;

The variability of the choice of the object's construction scheme (factor 1) is presented in table 1.

Table 1. Choice of the object construction scheme.

\begin{tabular}{|c|c|c|c|c|c|c|}
\hline $\begin{array}{c}\text { The number of the } \\
\text { organizational } \\
\text { structure } \\
\text { of the structure }\end{array}$ & D & TC & $\mathbf{E S}$ & PPD & PC & $\begin{array}{c}\text { The number of } \\
\text { main } \\
\text { participants } \\
\text { in the construction }\end{array}$ \\
\hline Scheme 1 & + & - & - & - & - & 1 \\
\hline Scheme 2 & + & - & - & - & + & 2 \\
\hline Scheme 3 & + & - & - & + & + & 3 \\
\hline Scheme 4 & + & - & + & + & + & 4 \\
\hline Scheme 5 & + & + & + & + & + & 5 \\
\hline Scheme 6 & + & - & \multicolumn{2}{|c|}{$T$} & + & 3 \\
\hline Scheme 7 & + & - & + & \multicolumn{2}{|c|}{+} & 3 \\
\hline Scheme 8 & + & - & \multicolumn{3}{|c|}{+} & 2 \\
\hline Scheme 9 & + & + & \multicolumn{3}{|c|}{+} & 3 \\
\hline
\end{tabular}

Note: PD - a property developer; ES - a person performing engineering surveys under an agreement with the property developer (technical customer); PC - the person carrying out the construction of the contract with the property developer (technical customer); PPD - the person performing the preparation of project documentation under the contract with the property developer (technical customer); TC — the person authorized by the property developer to perform the functions of a technical customer.

1.2 The choice of the method of construction of the object is determined by the scheme of contracts (general contracting method of construction, contracting method of construction, etc.);

1.3 Distribution of functionality between the construction participants - the property developer, engineering company, technical customer.

Factor 2. The quality laid down when creating an organization performing the functions of a property developer and forming its structure:

2.1 level of the possibility of self-realization of the functions of the property developer without the involvement of a technical customer;

2.2 the presence of a sufficient number of employees performing the functions of the property developer, including specialists in the implementation of control measures for the construction control of the property developer;

2.3 degree of organization mobility (availability of the possibility of forming a representative office directly on the construction site);

2.4 availability of an organization's quality management system certified in accordance with the established procedure.

2.5 the presence in a sufficient amount of its own instrumentation base for monitoring;

2.6 presence of quality services;

2.7 the number of levels of management of the organization;

2.8 a distance from the control centre to the control object;

2.9 availability and number of inspection services.

Factor 3. The quality laid down when creating an organization performing the functions of a person performing engineering surveys and shaping its structure: 
3.1 level of specialization;

3.2 the presence in a sufficient number of workers, including specialists in the organization of engineering surveys, information about which is included in the national register of specialists in the field of engineering surveys and architectural and construction design;

3.3 degree of organization mobility;

3.4 availability of an organization's quality management system certified in accordance with the established procedure;

3.5 Presence in a sufficient number of its own mechanization, transport, production base;

3.6. Availability of quality services and laboratory control services accredited in the established procedure in the national accreditation system;

3.7 the number of levels of management of the organization;

3.8 distance from the control centre to the control object;

3.9 availability and number of inspection services.

Factor 4. The quality laid down in the creation of an organization engaged in the preparation of project documentation and the formation of its structure:

4.1 level of specialization;

4.2 the presence of a sufficient number of employees, including specialists in the organization of architectural and construction design, information about which is included in the national register of specialists in the field of engineering surveys and architectural and construction design;

4.3 degree of organization mobility;

4.4 availability of an organization's quality management system certified in accordance with the established procedure;

4.5 the presence in a sufficient number of its own software and settlement systems;

4.6 The presence in its composition of quality services and services that carry out conformity assessment, including the standard control of the developed design products;

4.7 the number of levels of management of the organization;

4.8 distance from the control centre to the control object;

4.9 availability and number of inspection services.

Factor 5. The quality laid down when creating an organization performing the functions of a person carrying out construction and forming its structure:

5.1 specialization level;

5.2 Presence sufficient number of workers, including specialists in the organization of construction, information about which is included in the national register of specialists in the field of construction.

5.3 degrees of mobility;

5.4 availability of an organization's quality management system certified in accordance with the established procedure;

5.5 Presence in a sufficient number of its own mechanization, transport, production base (the degree of the possibility of performing more work without the involvement of contractors);

5.6 presence in its composition of quality services and laboratory control services accredited in the prescribed manner in the national accreditation system;

5.7 number of levels of management of the organization;

5.8 distance from the control centre to the control object;

5.9 availability and number of inspection services.

Factor 6. The security of construction, production, design and working documentation developed on its basis before the start of construction work. Quality of project and working documentation. 
Factor 7. Manufacturability of design solutions (low-operational technology; an increase in the amount of work carried out in an automated way; industrialization of solutions).

Factor 8. Provision of construction production with organization-technological and production-technological documentation (PPR, technological regulations, operational control cards, etc.). The quality of organizational and technological and production and technological documentation.

Factor 9. High factory (shop) readiness of structural elements, parts, products.

Factor 10. Rhythmic and complete supply of building materials and products, process equipment.

Factor 11. The use of modern high-performance machinery and equipment for construction production.

Factor 12. Violation of the periodicity of advanced training of workers and engineers; minimization of personnel rotation; rational combination of professions.

Factor 13. The possibility of freezing regulatory requirements.

Factor 14. Failure of machines and mechanisms of construction production.

Factor 15. Failure of networks of energy and water.

Factor 16. Low quality building materials and process equipment.

Factor 17. The presence of changes in design and working documentation.

Factor 18. Violations of construction technology.

Factor 19. Lack of engineers and workers required specialties and the necessary qualification level of workers.

Factor 20. Unfavourable climatic conditions, weather conditions (climatic factor).

Factor 21. Failure of the team / workers to perform the necessary work with full support of the work, deliberate damage to or theft of materials, equipment, employee's absenteeism of the construction site (social factor).

Factor 22. Force Majeure.

Factor 23. The attractiveness of the construction industry in terms of price per unit of work.

Factor 24. Availability and implementation of quality assurance programs for the construction of nuclear facilities.

Factor 25. The existence and operation of a nonconformity management system using the $8 \mathrm{D}$ methodology.

\section{Results \& discussion}

Thus, it is proposed to assess the level of the construction quality assurance system, taking into account the quality of organizational decisions and the main factors cited:

$$
K_{S Q}=f\left(K_{F_{2}}^{a} \times K_{F_{3}}^{b} \times K_{F_{4}}^{c} \times K_{F_{5}}^{d} \times K_{F_{6}} \times \ldots \times K_{F_{25}}\right) \times k_{C L}(P D) \times k_{C L}(E S) \times
$$

where: $k_{S Q}-$ an indicator of the level of the construction quality assurance system varies in the range $0 \ldots 1$;

$k_{C L}(P D) \times k_{C L}(E S) \times k_{C L}(P P D) \times k_{C L}(P C)$

$k_{C L}$-the complex coefficient of controllability in the construction of the object;

$K_{F_{N}}$ - assessment of the influence of the factor on the construction quality assurance system;

$a, b, c, d$ - the weighting coefficients of a factor in carrying out the functions of the property developer, in performing engineering surveys, in developing design products 
(design and working documentation), and during construction, respectively $(\mathrm{a}=0.35 ; \mathrm{b}=$ $0.15 ; \mathrm{c}=0.20 ; \mathrm{d}=0.30$;

$k_{C L}(\mathrm{PD})$ - the complex coefficient of controllability in the implementation of the functions of the property developer;

$$
k_{C L}(\mathrm{PD})=\alpha /(1+\beta+\mu+\varphi)
$$

where: $\alpha=1$;

$\beta-$ the number of organizations involved by the developer to perform the functions of a technical customer in engineering surveys;

$\mu$ - the number of organizations involved by the developer to exercise the functions of a technical customer in the development of design products;

$\varphi$ - the number of organizations involved by the developer to perform the functions of a technical customer in the implementation of construction.

$k_{C L}(\mathrm{ES})$ - the coefficient of controllability in the implementation of the process engineering surveys;

$$
k_{C L}(E S)=\alpha /(1+\beta+\mu)
$$

where: $\alpha=1$;

$\beta$ - the number of organizations involved by the developer or technical customer for the implementation of engineering surveys;

$\mu$ - the number of contracting organizations attracted by the person carrying out engineering surveys.

$k_{C L}$ (PPD) - the coefficient of controllability in the implementation of the process - the development of design products;

$$
k_{C L}(P P D)=\alpha /(1+\beta+\mu)
$$

where: $\alpha=1$;

$\beta$ - the number of organizations attracted by the developer or technical customer for the development of design products;

$\mu-$ the number of contracting organizations attracted by the person engaged in the development of design products.

$k_{C L}(\mathrm{PC})$ - the coefficient of controllability in the implementation of the process construction;

$$
k_{C L}(\mathrm{PC})=\alpha /(1+\beta+\mu)
$$

where: $\alpha=1$;

$\beta$ - the number of organizations attracted by the developer or technical customer for construction;

$\mu$ - the number of contracting organizations attracted by the person carrying out the construction.

If the developer or technical customer engages one organization to carry out engineering surveys and design products, or to develop design products and construction or to carry out engineering surveys and construction, the corresponding controllability factors are 
calculated using the following formulas:

$$
k_{C L}(\mathrm{ES}+\mathrm{PPD})=\alpha /(1+\beta+\mu)
$$

where: $\alpha=1$;

$\beta-$ the number of organizations attracted by the developer or technical customer for the implementation of engineering surveys and the development of design products;

$\mu$ - the number of contracting organizations attracted by the person carrying out engineering surveys and the development of design products.

$$
k_{C L}(\mathrm{PPD}+\mathrm{PC})=\alpha /(1+\beta+\mu)
$$

where: $\alpha=1$;

$\beta$ - the number of organizations involved by the developer or technical customer for the development of design products and construction;

$\mu$ - the number of contracting organizations attracted by the person engaged in the development of design products and construction.

$$
k_{C L}(\mathrm{ES}+\mathrm{PC})=\alpha /(1+\beta+\mu)
$$

where: $\alpha=1$;

$\beta-$ the number of organizations attracted by the developer or technical customer for the implementation of engineering surveys and construction

$; \mu$ - the number of contracting organizations attracted by a person performing engineering surveys and carrying out construction.

If the developer or technical customer engages one organization to carry out engineering surveys, design products and construction, the calculation of the corresponding controllability coefficient is performed using the following formula:

$$
k_{C L}(\mathrm{ES}+\mathrm{PPD}+\mathrm{PC})=\alpha /(1+\beta+\mu)
$$

where: $\alpha=1$;

$\beta$ - the number of organizations attracted by the developer or technical customer for the implementation of engineering surveys, the development of design products, construction;

$\mu$ - the number of contracting organizations attracted by a person performing engineering surveys, developing design documentation and construction.

Thus, the complex controllability coefficient for the construction of the object is maximum in the case of the implementation of the facility's construction scheme, when the property developer independently performs engineering surveys, designs and carries out construction $\left(\mathrm{k}_{\mathrm{CL}}=1\right)$ and if the engineering scheme of the structure is constructed $\left(\mathrm{k}_{\mathrm{CL}}=\right.$ 1 ), when an engineering company is engaged to carry out engineering surveys, design products and construction.

When choosing a facility construction scheme, when the property developer engages various organizations performing engineering surveys, preparing project documentation and construction, respectively (without the participation of a technical customer) $\mathrm{k}_{\mathrm{CL}}=0.125$, in engineering survey, design and construction works. And, accordingly, when choosing a facility construction scheme, when a property developer engages various organizations performing engineering surveys, preparing project documentation and construction 
respectively (with the participation of a technical customer) $\mathrm{k}_{\mathrm{CL}}=0.0625$, the property developer engages in engineering survey, design and construction.

The dependence of the coefficient of controllability on the choice of the organizational scheme for the construction of an object calculated by the formula is presented in Table 2 and Table 3 shows the values of the factors' influence factors on the quality assurance system for the construction of the object.

Table 2. Dependence of the coefficient of controllability on the choice of the object construction scheme

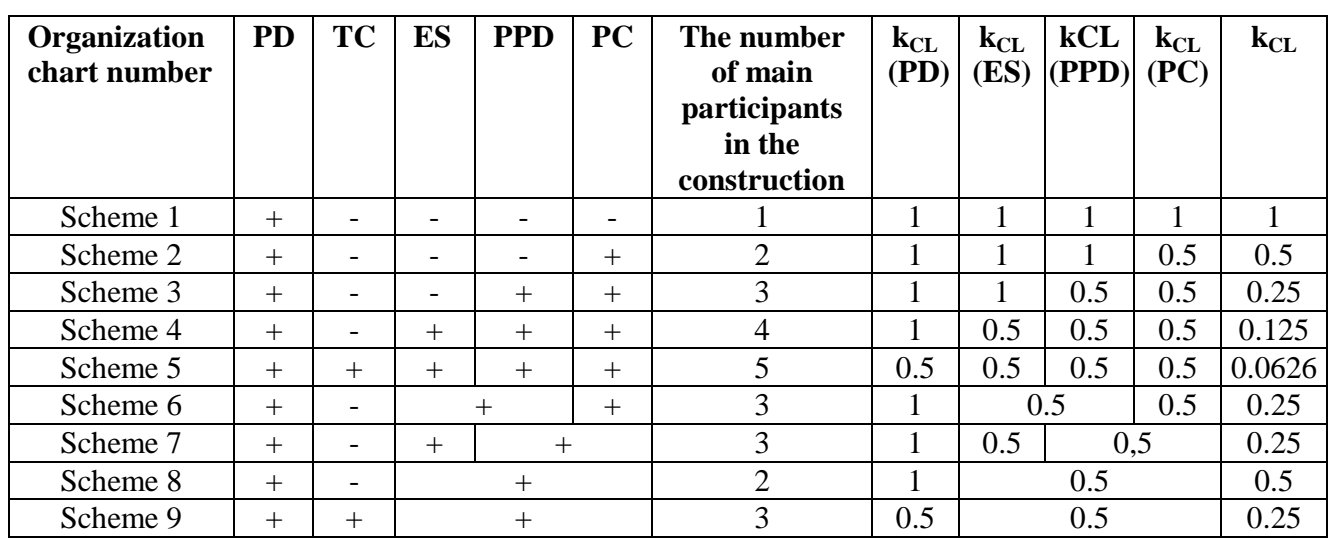

Note: PD - a property developer; ES - a person performing engineering surveys under an agreement with the property developer (technical customer); PC — the person carrying out the construction of the contract with the property developer (technical customer); PPD - the person performing the preparation of project documentation under the contract with the property developer (technical customer); TC — the person authorized by the property developer to perform the functions of a technical customer.

Table 3. Values of factors of influence of the factor on the quality assurance system of the facility construction.

\begin{tabular}{|c|c|l|c|}
\hline N & $\begin{array}{c}\text { Factor } \\
\text { number }\end{array}$ & \multicolumn{1}{|c|}{ The name of the factor } & $\begin{array}{c}\text { The } \\
\text { coefficient } \\
\text { for the } \\
\text { influence } \\
\text { of the } \\
\text { factor }\end{array}$ \\
\hline 1. & 2 & $\begin{array}{l}\text { The quality laid down when creating an organization performing the } \\
\text { functions of a property developer and forming its structure }\end{array}$ & $\sum 2.1-2.9$ \\
\hline 2. & 2.1 & $\begin{array}{l}\text { the possibility of independent implementation of the functions of the } \\
\text { property developer without the involvement of a technical customer }\end{array}$ & 0.03 \\
\hline 3. & 2.2 & $\begin{array}{l}\text { the presence of a sufficient number of employees performing the } \\
\text { functions of the property developer, including specialists in the } \\
\text { implementation of control measures for the construction control of the } \\
\text { property developer }\end{array}$ & 0.03 \\
\hline 4. & 2.3 & $\begin{array}{l}\text { the degree of mobility of the organization (the possibility of forming a } \\
\text { representative office directly on the construction site) }\end{array}$ & 0.03 \\
\hline 5. & 2.4 & $\begin{array}{l}\text { availability of an organization-certified quality management system } \\
\text { presence in sufficient quantity of own instrumental base for control }\end{array}$ & 0.09 \\
\hline 6. & 2.5 & prestionce of quality service in the organization & 0.03 \\
\hline 7. & 2.6 & presence & 0.06 \\
\hline 8. & 2.7 & the number of levels of management of the organization (compliance & $\ldots$ \\
\hline
\end{tabular}




\begin{tabular}{|c|c|c|c|}
\hline & & $\begin{array}{l}\text { of the controllability standard with the established requirements, an } \\
\text { example of requirements is presented in Table } 4 \text { ) }\end{array}$ & \\
\hline 9. & 2.8 & $\begin{array}{l}\text { distance from the control center to the control object (minimum } \\
\text { distance) }\end{array}$ & $\cdots$ \\
\hline 10. & 2.9 & availability of inspection services & 0.03 \\
\hline 11. & 3 & $\begin{array}{l}\text { The quality laid down when creating an organization performing the } \\
\text { functions of a person performing engineering surveys and shaping its } \\
\text { structure }\end{array}$ & $\sum 3.1-3.9$ \\
\hline 12. & 3.1 & level of specialization (meets / does not match) & $\ldots$ \\
\hline 13. & 3.2 & $\begin{array}{l}\text { the presence of a sufficient number of employees, including } \\
\text { specialists in the organization of engineering surveys, information } \\
\text { about which is included in the national register of specialists in the } \\
\text { field of engineering surveys and architectural and construction design }\end{array}$ & $\ldots$ \\
\hline 14. & 3.3 & organization mobility degree & $\ldots$ \\
\hline 15. & 3.4 & availability of an organization-certified quality management system & $\ldots$ \\
\hline 16. & 3.5 & $\begin{array}{l}\text { the presence in a sufficient number of their own mechanization, } \\
\text { transport, production base }\end{array}$ & $\cdots$ \\
\hline 17. & 3.6 & $\begin{array}{l}\text { presence of quality services and laboratory control services accredited } \\
\text { in accordance with the established procedure in the national } \\
\text { accreditation system }\end{array}$ & $\cdots$ \\
\hline 18. & 3.7 & $\begin{array}{l}\text { the number of levels of the organization's management (compliance } \\
\text { of the controllability standard with the established requirements, an } \\
\text { example of the requirements is presented in Table 4) }\end{array}$ & $\ldots$ \\
\hline 19. & 3.8 & distance from the control center to the control object & $\ldots$ \\
\hline 20. & 3.9 & availability of inspection services & $\ldots$ \\
\hline 21. & 4 & $\begin{array}{l}\text { The quality laid down when creating an organization that prepares } \\
\text { project documentation and shaping its structure }\end{array}$ & $\sum 4.1-4.9$ \\
\hline 22. & 4.1 & level of specialization & $\ldots$ \\
\hline 23. & 4.2 & $\begin{array}{l}\text { the presence of a sufficient number of workers, including specialists } \\
\text { in the organization of architectural and construction design, } \\
\text { information about which is included in the national register of } \\
\text { specialists in the field of engineering surveys and architectural and } \\
\text { construction design }\end{array}$ & $\cdots$ \\
\hline 24. & 4.3 & organization mobility degree & $\ldots$ \\
\hline 25. & 4.4 & availability of an organization-certified quality management system & $\ldots$ \\
\hline 26. & 4.5 & $\begin{array}{l}\text { the presence in a sufficient number of its own software and settlement } \\
\text { systems }\end{array}$ & $\cdots$ \\
\hline 27. & 4.6 & $\begin{array}{l}\text { availability of quality services and services for conformity } \\
\text { assessment, including the standard control of the developed design } \\
\text { products }\end{array}$ & $\cdots$ \\
\hline 28. & 4.7 & $\begin{array}{l}\text { the number of steps of the organization's management (compliance of } \\
\text { the controllability standard with the established requirements, an } \\
\text { example of the requirements is presented in Table } 4 \text { ) }\end{array}$ & $\ldots$ \\
\hline 29. & 4.8 & distance from the control center to the control object & $\ldots$ \\
\hline 30. & 4.9 & availability of inspection services & $\ldots$ \\
\hline 31. & 5 & $\begin{array}{l}\text { The quality laid down when creating an organization performing the } \\
\text { functions of a person carrying out construction and forming its } \\
\text { structure: }\end{array}$ & $\sum 5.1-5.9$ \\
\hline 32. & 5.1 & level of specialization & $\ldots$ \\
\hline 33. & 5.2 & $\begin{array}{l}\text { the presence of a sufficient number of workers, including specialists } \\
\text { in the organization of construction, information about which is } \\
\text { included in the national register of specialists in the field of } \\
\text { construction }\end{array}$ & ․ \\
\hline 34. & 5.3 & degree of mobility & $\ldots$ \\
\hline 35. & 5.4 & availability of an organization-certified quality management system & $\cdots$ \\
\hline 36. & 5.5 & availability of own mechanization, transport, production base in a & \\
\hline
\end{tabular}




\begin{tabular}{|c|c|c|c|}
\hline & & $\begin{array}{l}\text { sufficient number of (the degree of the possibility of performing more } \\
\text { work without the involvement of contractors) }\end{array}$ & \\
\hline 37. & 5.6 & $\begin{array}{l}\text { presence of quality services and laboratory control services accredited } \\
\text { in accordance with the established procedure in the national } \\
\text { accreditation system }\end{array}$ & .. \\
\hline 38. & 5.7 & $\begin{array}{l}\text { the number of steps of the organization's management (compliance of } \\
\text { the controllability standard with the established requirements, an } \\
\text { example of the requirements is presented in Table 4) }\end{array}$ & $\ldots$ \\
\hline 39. & 5.8 & distance from the control center to the control object & $\ldots$ \\
\hline 40. & 5.9 & availability and number of inspection services & $\ldots$ \\
\hline 41. & 6 & $\begin{array}{l}\text { Provision of construction production with design and working } \\
\text { documentation developed on its basis prior to the start of construction } \\
\text { work. Quality of project and working documentation }\end{array}$ & 0.01 \\
\hline 42. & 7 & $\begin{array}{l}\text { Manufacturability of design decisions (low-operational technology; } \\
\text { increase in the amount of work carried out in an automated way; } \\
\text { industrialization of solutions) }\end{array}$ & 0.02 \\
\hline 43. & 8 & $\begin{array}{l}\text { Provision of construction production with organizational, } \\
\text { technological and production and technological documentation (PPR, } \\
\text { technological regulations, operational control cards, etc.). Quality of } \\
\text { organizational and technological and production and technological } \\
\text { documentation }\end{array}$ & 0.02 \\
\hline 44. & 9 & High factory (shop) readiness of structural elements, parts, products & 0.03 \\
\hline 45. & 10 & $\begin{array}{l}\text { Rhythmic and complete supply of construction materials and } \\
\text { products, technological equipment }\end{array}$ & 0.02 \\
\hline 46. & 11 & $\begin{array}{l}\text { The use of modern high-performance machinery and equipment for } \\
\text { construction production }\end{array}$ & 0.02 \\
\hline 47. & 12 & $\begin{array}{l}\text { Violation of the periodicity of advanced training of workers and } \\
\text { engineering personnel; minimization of personnel rotation; rational } \\
\text { combination of professions }\end{array}$ & 0.005 \\
\hline 48. & 13 & Ability to freeze regulatory requirements & $\ldots$ \\
\hline 49. & 14 & Failure of machines and mechanisms of construction production & $\ldots$ \\
\hline 50. & 15 & Failure of networks of energy and water & $\ldots$ \\
\hline 51. & 16 & Low quality building materials and process equipment & $\ldots$ \\
\hline 52. & 17 & The presence of changes in design and working documentation & $\ldots$ \\
\hline 53. & 18 & Violations of construction technology & $\ldots$ \\
\hline 54. & 19 & $\begin{array}{l}\text { Lack of engineers and workers required specialties and the necessary } \\
\text { qualification level (level) of workers }\end{array}$ & $\cdots$ \\
\hline 55. & 20 & Adverse climatic conditions, weather conditions (climatic factor) & $\ldots$ \\
\hline 56. & 21 & $\begin{array}{l}\text { Failure of the team / workers to perform the necessary work with full } \\
\text { support of the work, deliberate damage or theft of materials, } \\
\text { equipment, employee's absenteeism to the construction site (social } \\
\text { factor) }\end{array}$ & .. \\
\hline 57. & 22 & Force majeure & $\ldots$ \\
\hline 58. & 23 & $\begin{array}{l}\text { The attractiveness of the construction industry in terms of price per } \\
\text { unit of work }\end{array}$ & $\cdots$ \\
\hline 59. & 24 & $\begin{array}{l}\text { Availability and implementation of quality assurance programs for the } \\
\text { construction of nuclear facilities }\end{array}$ & $\cdots$ \\
\hline 60. & 25 & $\begin{array}{l}\text { Availability and operation of a nonconformity management system } \\
\text { using the } 8 \mathrm{D} \text { methodology }\end{array}$ & $\cdots$ \\
\hline
\end{tabular}

The rate of control is determined by the formula:

$$
N_{\text {Det }}=(x-y) / y,
$$

where: $N_{\text {Det }}-$ the rate of control; 
$x$ - the total number of established units in the organization;

$y$ - the number of staff units of managers.

Table 4 shows an example of the manageability standard for organizations of various sizes.

Table 4. An example of the norm of controllability for organizations of different size.

\begin{tabular}{|c|c|c|c|c|c|}
\hline \multirow{2}{*}{ Type of organization } & \multicolumn{5}{|c|}{ Number of employees in the organization } \\
\cline { 2 - 6 } & $\mathbf{1 5 0 . . 5 0 0}$ & $\mathbf{5 0 0 \ldots 1 0 0 0}$ & $\mathbf{1 0 0 0 . . . 3 0 0 0}$ & $\mathbf{3 0 0 0 \ldots . 5 0 0 0}$ & $\begin{array}{c}\mathbf{5 0 0 0} \\
\text { and } \\
\text { more }\end{array}$ \\
\hline Property developer & 6 & 7 & 8 & 9 & 12 \\
\hline $\begin{array}{c}\text { Organizations performing } \\
\text { engineering surveys, } \\
\text { developing design products }\end{array}$ & 6 & 6 & 7 & 8 & - \\
\hline Construction organizations & - & 7 & 7 & 8 & 10 \\
\hline
\end{tabular}

\section{Conclusions}

Based on the above provisions, it can be argued that the improvement of the assessment process and the adoption of organizational decisions to ensure the quality of construction objects is aimed at increasing their validity through the use of formalized techniques, optimizing the basic technical and economic indicators of the construction of buildings and structures of "cost-duration-quality" and should consider: features of the construction industry (including organizational forms and structures, methods used), compliance with development of the quality assurance subsystem for the future tasks of investment and construction activities, as well as the specifics of the interaction of its participants.

As further tasks in this area, we can highlight the need to find quantitative expression methods for a number of factors presented in this work that influence the quality of organizational decisions and ensure the quality of construction in general: the quality indicator of design and working documentation; indicator of high factory (shop) readiness of structural elements, parts, products; the rate of application of modern high-performance machines and equipment for construction; quality indicator of building materials, process equipment, etc.

\section{References}

1. Bayburin A.Kh. El. res., http://pamag.ru/src/pressa/145.pdf

2. A.A. Gusakov etc. Organizational and technological reliability of construction (SvR Argus, 1994)

3. E.E. Bachus, Scientific Review, 20 (2016)

4. S.B. Sborshikov, N.V. Lazareva, E.E.Bachus, Scien.-Th. Journ. of the Belgorod STU 186 (2017)

5. S.B. Sborshikov, N.V. Lazareva, E.E.Bachus, Scien.-Th. Journ. of the Belgorod STU 220 (2017)

6. S.B. Sborshikov, P.A. Zhuravlev, E.E.Bachus, J. ICE 76 (2018)

7. P.A. Zhuravlev, Bulletin of the Irkutsk STU 104 (2015)

8. P.A. Zhuravlev, V.D. Kluev, V.G. Evseev, Scientific Review, 209 (2014)

9. V.D. Kluev, V.G. Evseev, Scientific Review, 214 (2014) 
10. E.E. Ermolaev, Bulletin of State University of Management 3 (2013)

11. A.A. Aleksanin, Scientific Review, 378 (2015)

12. S.B. Sborshikov, A.A. Aleksanin, MATEC WC IPICSE 180(2016)

13. Y.V. Zharov, Journal of Industrial and Civil Engineering 69 (2013)

14. A.V. Lyapin, B.Y. Lyapin., Scientific Review, 251 (2016)

15. N.M. Shoumeiko, Bulletin of Civil Engineers 53 (2015)

16. N.M. Shoumeiko, Bulletin of Civil Engineers 19 (2016) 